\title{
Transformation of a University Lecture Hall in Valladolid (Spain) into a NZEB: LCA of a BIPV System Integrated in Its Façade
}

\author{
Gloria Y. Palacios-Jaimes, ${ }^{1}$ Pablo Martín-Ramos, ${ }^{2}$ Francisco J. Rey-Martínez, ${ }^{1}$ and \\ Ignacio A. Fernández-Coppel ${ }^{3}$ \\ ${ }^{1}$ Department of Energy Engineering and Fluid Mechanics, Universidad de Valladolid, Paseo del Cauce 59, 47011 Valladolid, Spain \\ ${ }^{2}$ Department of Agricultural and Environmental Sciences, EPS, Instituto de Investigación en Ciencias Ambientales (IUCA), \\ Universidad de Zaragoza, Carretera de Cuarte s/n, 22071 Huesca, Spain \\ ${ }^{3}$ Department of Materials Science and Metallurgical Engineering, Universidad de Valladolid, C/Francisco Mendizábal 1, 47014 \\ Valladolid, Spain
}

Correspondence should be addressed to Pablo Martín-Ramos; pmr@unizar.es

Received 29 April 2017; Accepted 13 August 2017; Published 19 September 2017

Academic Editor: Mahmoud M. El-Nahass

Copyright (c) 2017 Gloria Y. Palacios-Jaimes et al. This is an open access article distributed under the Creative Commons Attribution License, which permits unrestricted use, distribution, and reproduction in any medium, provided the original work is properly cited.

The EU Energy Performance of Buildings Directive (Directive 2010/31/EU) poses a major challenge, as it promotes the transformation of existing buildings into nearly zero-energy buildings (NZEB). In this work, we present the case of study of a lecture hall building, owned by the University of Valladolid (Spain), that is currently being refurbished into a NZEB by integration of renewable energy sources (RES), also in line with the requirements from Directive 2009/28/EC. As part of its major renovation, not only Trombe walls and geothermal energy are to be incorporated but also a building-integrated solar photovoltaic (BIPV) system to address the electricity needs and reduce the building's energy use and GHGs in a cost-effective manner. The environmental profile of this BIPV system has been investigated using life cycle impact assessment (LCIA), assessing the net emissions of $\mathrm{CO}_{2}$ and the damages caused in a comparative context with conventional electricity-generation pathways. In spite of the small power installed in this first stage (designed to cover only an annual energy consumption of about $13,000 \mathrm{kWh}$, around $6 \%$ of the total demand), it can be concluded that significant environmental benefits are gained using this system.

\section{Introduction}

A NZEB is defined in Article 2(2) of the Directive 2010/31/ EU as "a building that has a very high energy performance, as determined in accordance with Annex I. The nearly zero or very low amount of energy required should be covered to a very significant extent by energy from renewable sources, including energy from renewable sources produced on-site or nearby". This directive, adopted in 2010 and translated into RD 235/2013 in Spain, has led EU countries to significantly step up their efforts to take advantage of the opportunities presented by nearly zero-energy buildings, according to $\operatorname{COM}(2013) 483$ report. Further, the Commission recently published a Recommendation (EU) 2016/1318 on guidelines for the promotion of NZEBs and best practices to ensure that, by 2020, all new buildings are NZEBs. This emphasis can be mainly ascribed to the importance of the building sector for energy efficiency improvements and its contribution to energy security and the 2030 framework for climate and energy policy.

In parallel to requirements for new buildings, Article 9(2) also requires EU member states to put in place support policies to stimulate the refurbishment of existing building stocks-old and inefficient and frequently renovated at a slow pace-towards nearly zero-energy levels. Nonetheless, in contrast to new public-owned buildings (for which the 
NZEB concept will apply by 2019), in this case, there are no target dates or an obligation to set minimum energy performance requirements [1].

The University of Valladolid (UVa), a public university in the autonomous region of Castile and Leon (Spain), has made significant efforts in the past years to improve the energy efficiency of its buildings. The best example has been the LUCIA building, which has a zero $\mathrm{CO}_{2}$ balance (i.e., it is a real zero energy building, ZEB) and uses $100 \%$ RES, leading to a 98-point (Platinum) rating in the LEED (Leadership in Energy and Environmental Design) certification, ranking as the most efficient building in Europe and the second most efficient in the world (after Pixel building, in Australia) in 2015. Furthermore, it was chosen as a highlighted case in March 2016 by Build Up (the European portal for energy efficiency in buildings) as a showcase pioneer energy autonomous public building.

The UVa has now undertaken the transformation of several other existing buildings by implementing passive and bioclimatic design approaches to reduce energy demand in maintenance as well as only using on-site renewable energies (biomass, photovoltaic, and geothermal). One of these buildings is the lecture hall, in which on-site geothermal pipes are to be installed for both heating and cooling, in combination with passive heating systems (Trombe walls). Moreover, PV panels have also been integrated in the façade to cover the electricity needs. It is worth noting that, in terms of RES, PV panels are the most common option, with nearly $70 \%$ of the NZEB examples using them [2], and that the electricity energy demand for a NZEB can be relatively greater than the thermal energy demand due to the high insulation and high airtight envelope. In this regard, electricity generation via a PV system is essential for a NZEB, and PV systems (and in particular building-integrated photovoltaics) play an important role for NZEBs in terms of functionality and aesthetics.

Analyses of photovoltaic applications in ZEBs and NZEBs have received significant attention in the past two years (e.g., [3-5]), and cost-benefit analyses of NZEB energy efficiency strategies with on-site PV generation, such as that conducted by Pikas et al. [6], conclude that investments in PV systems for NZEB buildings for certain applications (e.g., offices) would be profitable without subsidies on energy sold back to the grid. However, while environmental impact analyses have been conducted for NZEB residential buildings (e.g., $[7,8])$, other studies on NZEB educational buildings, such as those by Ascione et al. [9], Niemelä et al. [10], Irulegi et al. [11], or Baran et al. [12], have not-to the best of the authors' knowledge-covered their LCA.

Taking into consideration that PV technology is associated with some environmental concerns (the production of PV cells is accompanied by a high rate of emissions during manufacturing, consequently causing a high impact on the environment, and the PV industry utilizes a variety of chemicals, many of which are relatively toxic to the human health and the environment, as noted by Menoufi et al. [13] (and references therein)), in the work presented herein, we have conducted a LCA analysis of the BIPV system installed so far in the lecture hall, designed to cover about $6 \%$ of the total building electricity demand, according to

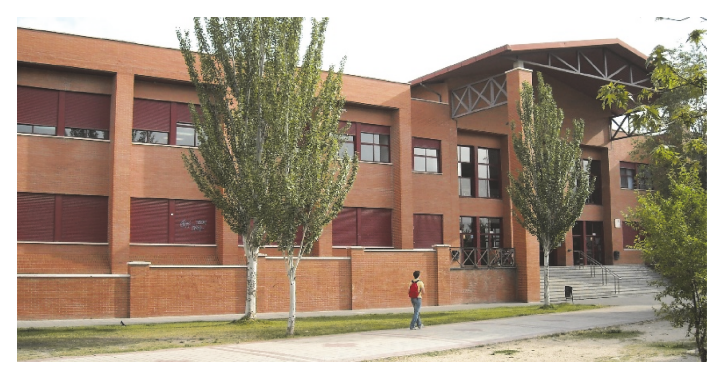

Figure 1: General view of the lecture hall building before the installation of the PV panels.

ISO 14040:2006 (Environmental management-Life cycle assessment-Principles and framework).

\section{Materials and Methods}

2.1. Case of Study. The lecture hall building (Figure 1) was built in 1992, and its energy performance was studied with LIDER-CALENER (Spanish Ministry of Energy) in 2009, according to Directive 2002/91/CE, resulting in a "C" energy class rating (annual $\mathrm{CO}_{2}$ emissions of $48.3 \mathrm{kgCO}_{2} / \mathrm{m}^{2}$ ). The average annual electricity consumption of the building over the 2006-2013 period was about $223,000 \mathrm{kWh}$ (i.e., $49 \mathrm{kWh} /\left(\mathrm{m}^{2} \cdot\right.$ year $\left.)\right)$, in good agreement with the energy simulations conducted using EnergyPlus (US-DOE-NREL) software (which resulted in an estimation of the electricity consumption of about $221,500 \mathrm{kWh} /$ year).

2.2. BIPV System Design. In a first stage of the transformation of the building, PV panels were to be installed as shades in its façade (Figure 2) to cover $6 \%$ of the total electricity demand (ca. 13,000 kWh/year). Table 1 summarizes the solar energy resources in the area of study $\left(41^{\circ} 39^{\prime} 29.4^{\prime \prime} \mathrm{N} 4^{\circ} 42^{\prime} 36.3^{\prime \prime} \mathrm{W}\right.$, $698 \mathrm{~m}$ AMSL).

In the design of the BIPV system, the optimum components' sizing and the orientation and inclination of the solar panels were evaluated and validated using PVsyst v.6 (PVsyst SA, Satigny, Switzerland) software (in line with other studies [15-17]), using a three-dimensional model to take into consideration the shadings (Figure 3), provided that partial shading has been identified as the main cause of yield and performance ratio (PR) reductions in PV systems [15].

It should also be clarified that, provided that the degradation of the modules reduces efficiency over the lifetime, a linear degradation declining to $80 \%$ of the initial efficiency at the end of a 30 -year lifetime (i.e., $0.7 \%$ per year or $10 \%$ on average during the entire lifetime [18]) has been assumed, according to IEA recommendations [19]. Thus, the total power generation of the BIPV system over its 30-year lifetime would add up to $350,033 \mathrm{kWh}$.

2.3. LCA Methodology. The reasoning behind the LCA is that the electricity produced by the PV installation will replace the same amount of electricity in the existing grid. If the environmental impact of the PV installation per kWh is smaller than the one for the grid electricity production, there will be a net saving of environmental damage. 


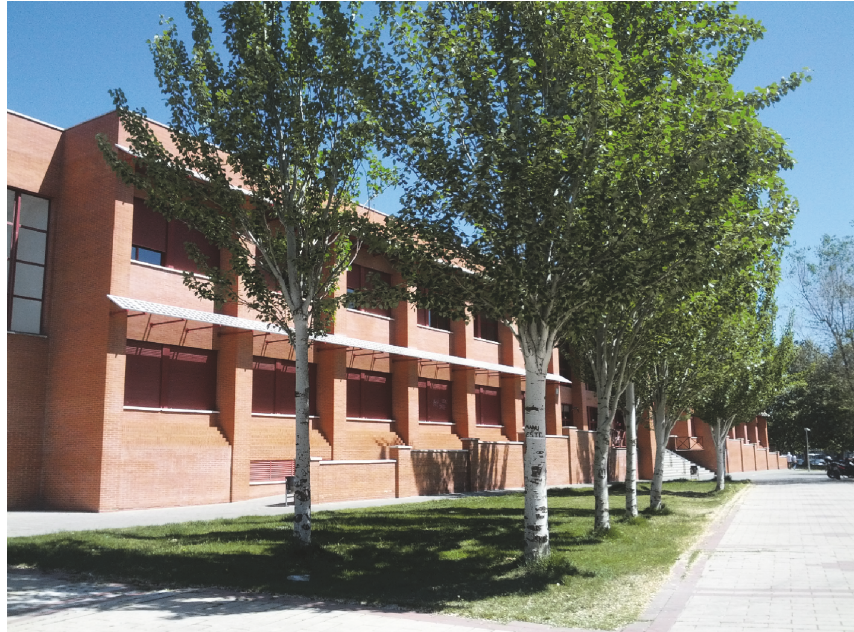

(a)

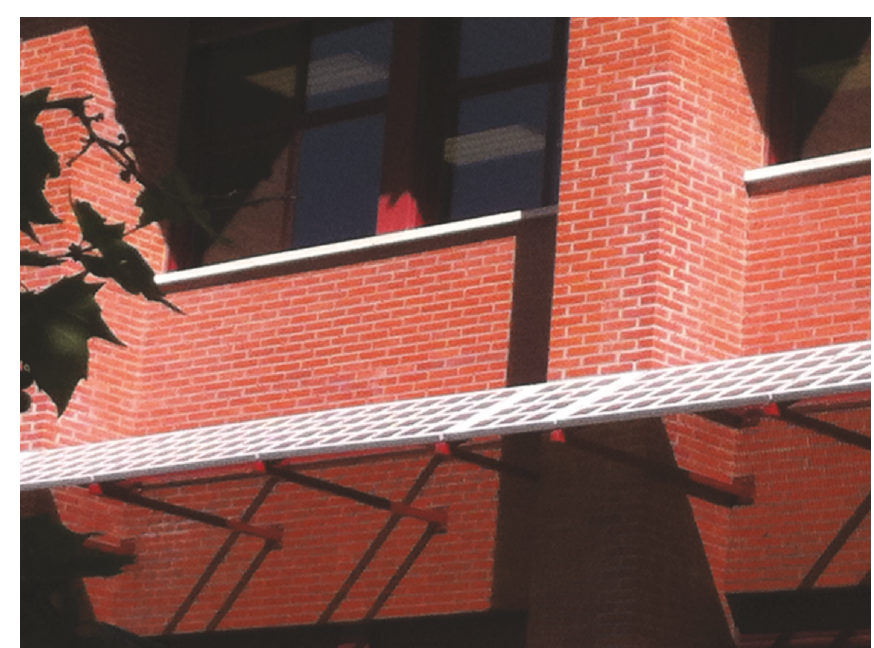

(b)

Figure 2: General view of the lecture hall façade after the installation of the PV panels (a) and detail of the PV panels used as shades (b).

LCA is not a performance indicator but rather a research method used for the quantitative assessment of material used, energy flows, and environmental impacts of products. It has been widely applied in the building industry, because it cannot only provide a more comprehensive and reasonable analysis on the energy and environment impact for the whole life cycle but also be used to determine top design priorities and quantitatively inform sustainable design decision making for various buildings [20-24].

As regards the specific LCA analysis of PV systems, the most popular approach in the literature has been the Energy Payback Time (EPBT), which may not be sufficient, as it does not provide a comprehensive environmental performance prospective [13]. In response to this limitation and in line with other studies, in this paper, other LCIA methodologies have instead been used: the Eco-Indicator 99 (EI-99) method, the Environmental Priority Strategies in product design method (EPS 2000), and the Intergovernmental Panel on Climate Change (IPCC) 2013 method.

The selected attributional LCA (ALCA) approach provides a compilation of all relevant inputs and outputs, as well as an evaluation of the feasible environmental impacts. Life cycle assessments based on the standard specification ISO 14040:2006, as the one presented herein, consist of four interdependent elements: (i) the goal and scope definition, (ii) the life cycle inventory (LCI) analysis, (iii) the life cycle impact assessment, and (iv) the interpretation of the results. Due to the associated complex environmental modeling, the LCIA step is the most critical and data intensive one, but it can be dealt with through different LCA software programs. In this case, SimaPro 8 (Pre Sustainability, Amersfoort, The Netherlands) software was chosen. The most recent International Energy Agency (IEA) PVPS Task 12 guidelines [19, 25] were followed in the LCI and LCA to assure the consistency, balance, transparency, and quality of the analysis and to enhance the credibility and reliability of the results.

The functional unit for the LCA is defined as $1 \mathrm{~m}^{2}$ of module area (the most usual for quantifying environmental impacts of buildings or for quantifying energy gains on roofs), but $1 \mathrm{kWh}$ of electricity fed into the grid will also be used in the discussion for the comparison of the PV system as a replacement of the set of energy resources used in the Spanish power grid mix.

Regarding the system boundaries of the study, a "cradle to gate" approach was chosen, considering the whole life cycle of the BIPV system, including all expenses to produce required energies, materials, and auxiliaries (raw material acquisition, materials processing, and manufacturing phases); the transportation of produced and used modules; all inputs involved in the installation of the PV system; its maintenance during the utilization phase; and its treatment/disposal/recycling at the end of the system's life. The end-of-life phase has been modelled according to Latunussa et al. [26], considering the "FRELP process"-an innovative recycling process for c-Si PV waste aimed at maximizing the recovery of all the material fractions contained into the panels-and including the dismantling of the installation, collection, and transport.

In relation to the geographical scope, production was considered for various countries representing the actual cell and module production sites. All datasets on used materials and energies were based on country representative datasets. The use phase was assumed to be in Valladolid (Spain), as noted above.

The life cycle inventory was carried out using with Ecoinvent 3.1 and ELCD (European reference Life Cycle Database) databases (updated in June 2016, based on 2015 LCI data).

In respect to the life cycle impact assessment, as noted above, two damage-oriented LCIA methodologies were considered: the EI-99 methodology, which is taken as the reference methodology, and EPS 2000 methodology. LCIA methodologies differ in some parameters: the approach of modeling the environmental impact, the impact categories, the endpoint and damage categories considered, characterization, normalization, and weighting factors. Applying various methodologies assists in having a more comprehensive 
TABLE 1: Monthly average global and diffuse horizontal irradiance experimental values [14]; monthly average direct, diffuse, and global horizontal irradiance values calculated with PVsyst; and monthly average temperature values in the area of study.

\begin{tabular}{|c|c|c|c|c|c|c|}
\hline & \multicolumn{5}{|c|}{ Horizontal irradiance (kWh/m²/month) } & \multirow{3}{*}{ Temperature $\left({ }^{\circ} \mathrm{C}\right)$} \\
\hline & \multicolumn{2}{|c|}{ Experimental [14] } & \multicolumn{3}{|c|}{ PVsyst } & \\
\hline & Global & Direct & Global & Direct & Diffuse & \\
\hline January & 57.6 & 31.2 & 56.5 & 26.9 & 30.5 & 2.0 \\
\hline February & 90.3 & 54.3 & 77.8 & 45.1 & 32.7 & 3.50 \\
\hline March & 134.1 & 84.6 & 127.7 & 76.1 & 51.1 & 7.30 \\
\hline April & 165.9 & 105 & 152.1 & 91.3 & 60.8 & 9.80 \\
\hline May & 194.4 & 123 & 185.7 & 115.1 & 70.6 & 14.6 \\
\hline June & 226.5 & 160.8 & 207.9 & 145.5 & 62.4 & 19.9 \\
\hline July & 232.5 & 174.3 & 213.0 & 161.9 & 51.1 & 22.7 \\
\hline August & 203.7 & 147.6 & 185.4 & 137.2 & 48.2 & 22.3 \\
\hline September & 157.8 & 110.7 & 139.8 & 99.3 & 40.5 & 18.2 \\
\hline October & 100.8 & 62.7 & 92.7 & 57.5 & 35.2 & 12.6 \\
\hline November & 65.4 & 36.3 & 59.7 & 31.0 & 28.7 & 6.6 \\
\hline December & 49.2 & 25.5 & 48.1 & 23.6 & 24.5 & 3.3 \\
\hline Average & 139.9 & 93.0 & 128.9 & 84.2 & 44.7 & 11.9 \\
\hline Total & 1678.2 & 1116 & 1546 & 1010 & 536 & \\
\hline
\end{tabular}
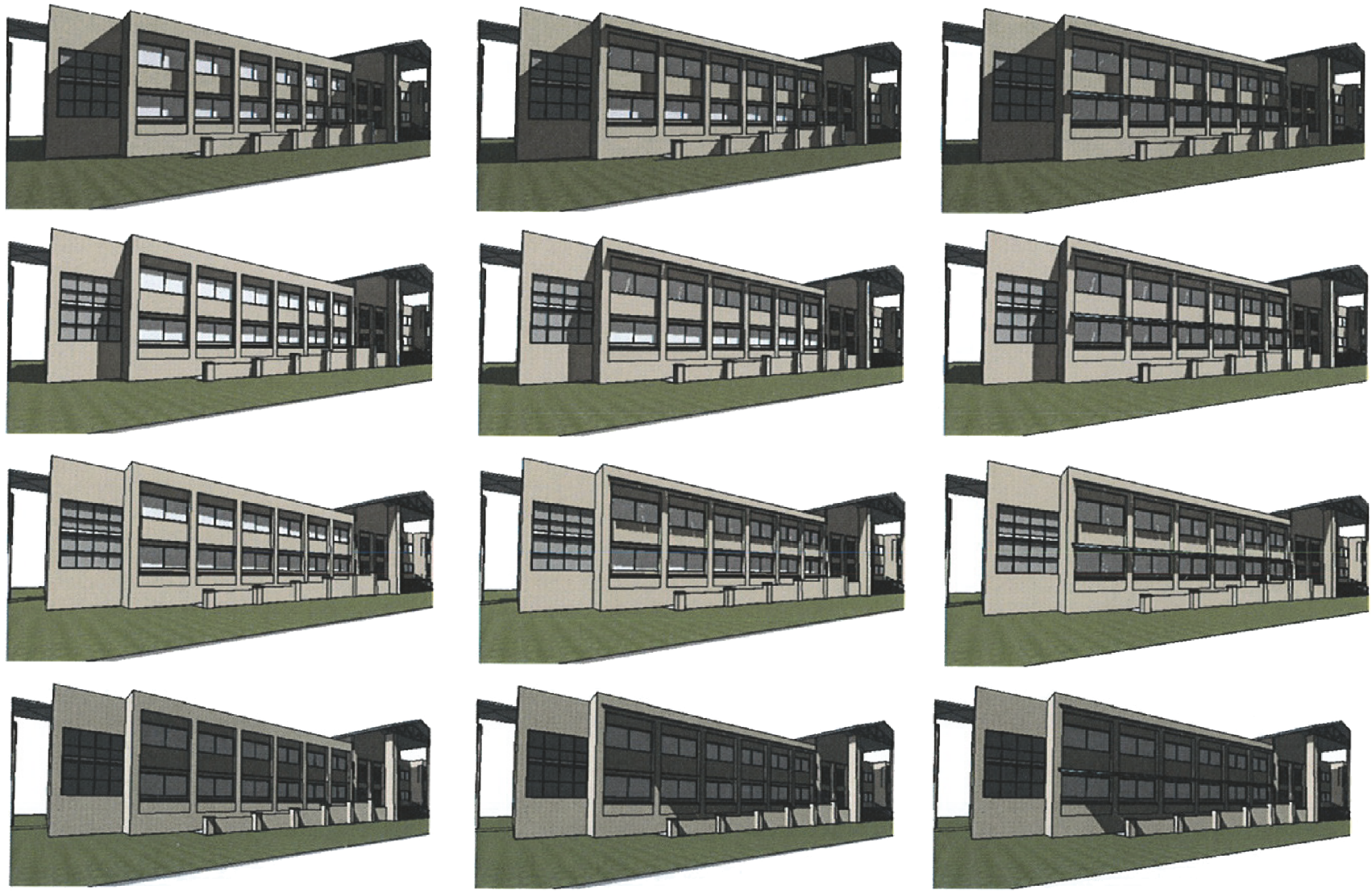

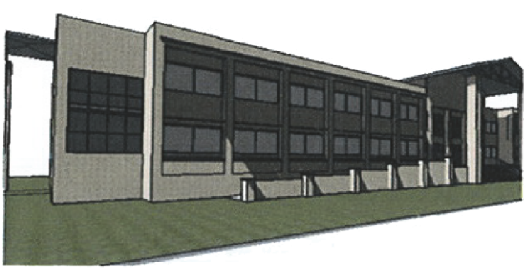

(b)

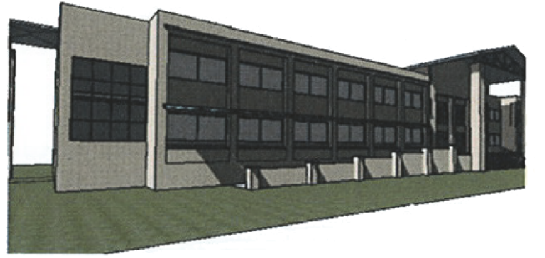

(c)

Figure 3: Examples of the shading analyses conducted with PVsyst: shading without panels (a), with the panels only above the top row of windows (b), and with the chosen solution-in which the panels are distributed above both rows of windows-(c) on 21 st of June at different times (from top to bottom: $10 \mathrm{am}$, noon, $2 \mathrm{pm}$, and $4 \mathrm{pm}$ ). 
TABLE 2: Impact assessment results using the EI-99 methodology per $1 \mathrm{~m}^{2}$ of module area (itemized by impact category).

\begin{tabular}{|c|c|c|c|c|c|c|c|}
\hline \multirow[b]{2}{*}{ Safeguard subject } & \multirow[b]{2}{*}{ Impact category } & \multicolumn{6}{|c|}{ Damage $(\mathrm{Pt})$} \\
\hline & & $\begin{array}{l}\text { Manufacturing } \\
\text { of PV panels }\end{array}$ & Installation $^{\dagger}$ & Maintenance & Dismantling & Recycling & Total \\
\hline \multirow{6}{*}{ Human health } & Carcinogens & 22.868 & 0.767 & 9.088 & 0.743 & 0.016 & 33.482 \\
\hline & Respiratory organics & 0.006 & 0.023 & 0.004 & 0.001 & 0.000 & 0.035 \\
\hline & Respiratory inorganics & 7.843 & 22.244 & 4.563 & 2.293 & 0.116 & 37.059 \\
\hline & Climate change & 0.675 & 3.086 & 0.530 & 0.337 & 0.017 & 4.645 \\
\hline & Ionizing radiation & 0.004 & 0.023 & 0.005 & 0.004 & 0.000 & 0.036 \\
\hline & Ozone layer depletion & 0.000 & 0.003 & 0.000 & 0.000 & 0.000 & 0.003 \\
\hline \multirow{3}{*}{$\begin{array}{l}\text { Ecosystem } \\
\text { quality }\end{array}$} & Ecotoxicity & 2.209 & 0.809 & 0.547 & 0.212 & 0.003 & 3.780 \\
\hline & $\begin{array}{l}\text { Acidification/ } \\
\text { eutrophication }\end{array}$ & 0.158 & 0.380 & 0.175 & 0.041 & 0.002 & 0.755 \\
\hline & Land use & 0.093 & 0.393 & 0.056 & 0.024 & 0.001 & 0.567 \\
\hline \multirow{2}{*}{ Resources } & Minerals & 1.347 & 0.542 & 0.261 & 0.152 & 0.001 & 2.304 \\
\hline & Fossil fuels & 1.369 & 7.268 & 2.230 & 0.669 & 0.042 & 11.577 \\
\hline Total & & 36.572 & 35.537 & 17.460 & 4.474 & 0.199 & 94.242 \\
\hline
\end{tabular}

${ }^{\dagger}$ Includes not only the transport and installation of the PV panels but also the manufacturing of all the other components of the BIPV system.

image of a system's environmental performance and its relative effects on the different environmental areas of protection. According to the structure of the version used of the EPS 2000 methodology, only characterization and weighting were considered, disregarding the normalization step, whereas in the EI-99 methodology characterization, normalization and weighting were considered. As in the work by Menoufi et al. [13], the final results are presented as single score impact indicators (score points). Those score points express the severity of the contribution of the impact categories to the environmental load and are to be regarded as dimensionless figures (the purpose is to compare relative differences between products and components, not the absolute value).

In connection with the carbon footprint, the global warming potential (GWP) of air emissions associated to the life cycle of the BIPV system was assessed with the IPCC 2013 method, which lists the climate change factor with a timeframe of 20 and 100 years and is based on the Intergovernmental Panel on Climate Change 2013 report [27]. Results were also compared with the values obtained from PVsyst, which includes a tool for calculating life cycle emissions (LCE) that by default considers only the operation of the PV installation (but not the construction, maintenance, or disposal). The carbon balance calculated by PVsyst was thus determined simply on the basis of the system's energy yield, its lifetime, and the grid's LCE (in which values published by the International Energy Agency (IEA) for the average $\mathrm{CO}_{2}$ emission in 2010 per $\mathrm{kWh}$ of electricity production for different countries or regions are used).

\section{Results and Discussion}

3.1. BIPV System. A system consisting of customized semitransparent glass-Tedlar ${ }^{\circledR}$ modules, supplied by Onyx Solar (Ávila, Spain), was chosen. Four strings of 25 photovoltaic glasses each, adding up to 100 connected modules, were connected to an IGPLUS $150 \mathrm{~V}-3$ (Fronius, Pettenbach, Austria) inverter. Out of the 25 photovoltaic glasses in each string, 18 were large panels $(1.430 \times 850 \mathrm{~mm})$ with $286^{\prime \prime}$ monocrystalline silicon (mono-Si) cells each and the other 7 were small panels $(650 \times 850 \mathrm{~mm})$ with $126^{\prime \prime}$ mono-Si cells each. The power per string was $2902.5 \mathrm{~W}$, with a maximum current of $36.36 \mathrm{~A}$, a maximum voltage of $380 \mathrm{~V}$, and a voltage drop of $7.66 \mathrm{~V}(2.04 \%)$.

The BIPV system accounts for a total surface of $106 \mathrm{~m}^{2}$ and has a peak power of $9.7 \mathrm{kWp}$, with an estimated annual power generation of ca. $13 \mathrm{MWh}$. Panels were installed with a $31^{\circ}$ tilt and a $14^{\circ} \mathrm{S}$ azimuth (Figure 3 ). The simulations with PVsyst showed that the adopted size gave good results.

3.2. LCA of the BIPV System. The impact assessment results per $1 \mathrm{~m}^{2}$ of module area from EI-99, which is the reference methodology used in this research, are summarized in Table 2: the PV panels manufacturing would account for most of the environmental impact (38.8\%), followed by the "installation" phase (37.7\%), the BIPV system maintenance (18.5\%), and its end-of-life phase (5\%). The high percentage value associated to the "installation" phase can be explained by the fact that it includes not only the transport and commissioning of the PV modules but also the manufacturing, transport, and commissioning of all the other elements needed for the PV system. The damage in this phase was mostly due to the electrical wiring (ca. $75.3 \%$ of the impact) versus $12.6 \%$ due to the steel support structures, $6.6 \%$ corresponding to other electronic components, and only $4.8 \%$ to the inverter.

Table 3 summarizes results using the EPS 2000 methodology, which were in reasonably good agreement; the highest percentage corresponded to the manufacturing of the PV panels (48.6\%) and the "installation" categories (33.5\%): ca. $72.6 \%$ of the impact would be associated with the wiring, $13.7 \%$ with the steel support structures, $7.9 \%$ with electronic components, and only $5.7 \%$ with the inverter. It is worth 
TABLE 3: Impact assessment results using the EPS 2000 methodology per $1 \mathrm{~m}^{2}$ of module area (itemized by impact category).

\begin{tabular}{|c|c|c|c|c|c|c|c|}
\hline \multirow[b]{2}{*}{ Safeguard subject } & \multirow[b]{2}{*}{ Impact category } & \multicolumn{6}{|c|}{ Damage $(\mathrm{Pt})$} \\
\hline & & $\begin{array}{l}\text { Manufacturing } \\
\text { of PV panels }\end{array}$ & Installation $^{\dagger}$ & Maintenance & Dismantling & Recycling & Total \\
\hline \multirow{5}{*}{ Human health } & Life expectancy & 80.980 & 23.586 & 12.366 & 7.489 & 0.404 & 124.825 \\
\hline & Severe morbidity & 15.205 & 3.125 & 2.227 & 1.311 & 0.072 & 21.940 \\
\hline & Morbidity & 2.323 & 0.569 & 0.406 & 0.253 & 0.013 & 3.565 \\
\hline & Severe nuisance & 3.051 & 5.340 & 0.817 & 0.114 & 0.002 & 9.324 \\
\hline & Nuisance & 1.150 & 0.601 & 0.261 & 0.123 & 0.006 & 2.141 \\
\hline \multirow{6}{*}{$\begin{array}{l}\text { Ecosystem production } \\
\text { capacity }\end{array}$} & Crop growth capacity & 0.124 & 0.036 & 0.053 & 0.013 & 0.001 & 0.227 \\
\hline & Wood growth capacity & -0.552 & -0.134 & -0.129 & -0.062 & -0.003 & -0.880 \\
\hline & $\begin{array}{c}\text { Fish and meat } \\
\text { production }\end{array}$ & -0.033 & -0.008 & -0.014 & -0.003 & 0.000 & -0.058 \\
\hline & Soil acidification & 0.026 & 0.014 & 0.007 & 0.003 & 0.000 & 0.050 \\
\hline & $\begin{array}{l}\text { Prod. cap. irrigation } \\
\text { water }\end{array}$ & 0.000 & 0.000 & 0.000 & 0.000 & 0.000 & 0.000 \\
\hline & Prod. cap. drinking water & 0.000 & 0.000 & 0.000 & 0.000 & 0.000 & 0.000 \\
\hline Abiotic stock resource & Depletion of reserves & 802.403 & 590.150 & 248.804 & 57.317 & 0.824 & 1699.498 \\
\hline Biodiversity & Species extinction & 0.581 & 0.157 & 0.122 & 0.080 & 0.003 & 0.943 \\
\hline Total & & 905.258 & 623.436 & 264.921 & 66.639 & 1.321 & 1861.575 \\
\hline
\end{tabular}

${ }^{\dagger}$ Includes not only the transport and installation of the PV panels but also the manufacturing of all the other components of the BIPV system.

noting that again the maintenance (14.2\%) and end-oflife $(3.7 \%)$ phase contributions to the total impact were comparatively low.

On the subject of the impact categories, the total impact score obtained with the EI-99 methodology is dominated by two impact categories associated with the damage to human health, namely, carcinogens (35.5\% of the total impact) and respiratory inorganics (39.3\%), followed by fossil fuels $(12.3 \%)$. This is attributed to the carcinogenic substances used and the emissions induced (which directly affect the respiratory health system) during the processing of the PV system constituting components. The depletion of the fossil fuel resources indicates the surplus energy that will be needed by the future generation in order to extract fossil fuels and use it to manufacture the corresponding components.

If instead we refer to the EPS 2000 analysis, one impact category prevails: the depletion of reserves (91.3\%), followed by life expectancy (6.7\%), and severe morbidity (1.2\%). The high score of the depletion of reserve impact category is explained by the high amount of fossil fuels extracted and used for the manufacturing of the used materials, while the life expectancy impact category reflects the expected shortening of average individual lifetimes (years of lost life) due to the impact of the corresponding manufacturing processes.

The differences between the results from the two methodologies should be ascribed to the fact that EPS 2000 method puts a great emphasis on the manufacturing phase, while EI-99 takes into consideration the entire life cycle. As mentioned above, the EI-99 methodology is considered as the reference, and EPS 2000 methodology is used in order to check and compare the coherency of the environmental performance results from another methodology perspective.
3.3. Comparative Environmental Performance versus the Power Grid Mix. Upon comparison of the BIPV system as replacement of the set of energy resources used in the power grid mix (Figure 4) according to the preferred methodology, namely, EI-99, it can be readily observed that there is a significant environmental benefit associated with the installation of the BIPV system: an impact reduction of ca. $53 \%$ is achieved through the implemented BIPV system.

With regard to the carbon footprint analysis, the climate change factor with a timeframe of 100 years was assessed using the IPCC 2013 methodology. The results indicate that the manufacturing phase would account for ca. $66.8 \%$ of the total emission, followed by the installation (14.3\%), the maintenance $(11.2 \%)$, and the end-of-life phase $(7.6 \%$ in the dismantling and $0.3 \%$ in the recycling). Throughout its 30 -year lifetime, the system would lead to emissions of $52,716 \mathrm{~kg} \mathrm{CO}$ eq. Since the total power generation of the BIPV system over its 30-year lifetime would add up to $350,033 \mathrm{kWh}$ (taking into consideration the decrease in efficiency due to degradation of the panels, as noted above), the emission factor would be $0.15 \mathrm{~kg} \mathrm{CO}$ eq $/ \mathrm{kWh}$. This value is in good agreement with those reported for a BICPV system for different cities (Barcelona, Seville, Paris, Marseille, London, and Aberdeen) [28]: Marseille and Seville showed the lowest values (less than $142 \mathrm{~g} \mathrm{CO} \mathrm{CO}_{2} \mathrm{eq} / \mathrm{kWh}$ ), while London, Paris, and Aberdeen showed higher GWP 159$171 \mathrm{~g} \mathrm{CO}_{2} \mathrm{eq} / \mathrm{kWh}$ (GWP 100a; 30-year scenario).

For the same electricity consumption, using the Spanish power grid mix would lead to emissions of $0.456 \mathrm{~kg}$ $\mathrm{CO}_{2} \mathrm{eq} / \mathrm{kWh}$ (an average of $0.257 \mathrm{~kg} \mathrm{CO} / \mathrm{kWh}$ over the 2013-2017 period + the carbon dioxide equivalents of all non- $\mathrm{CO}_{2}$ gases (namely, $\mathrm{CH}_{4}, \mathrm{~N}_{2} \mathrm{O}, \mathrm{SF}_{6}, \mathrm{HFCs}$, and CFCs)). Thus, the carbon footprint would be reduced by $67 \%$, thanks to the implementation of the BIPV system. 


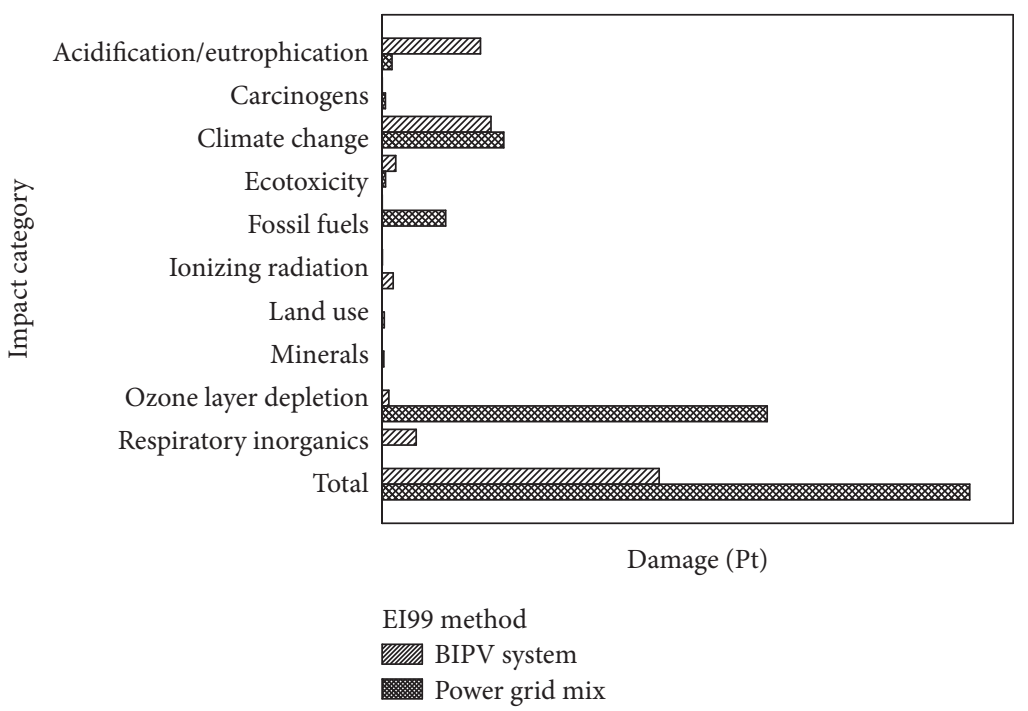

FIGURE 4: Environmental impacts ascribed to electricity consumption from Spanish power grid and from on-site PV panels, according to EI-99 methodology.

TABLE 4: Impact of BIPV system lifetime assumption on the emission factor, considering a reduction in the module efficiency of $0.7 \%$ per year.

\begin{tabular}{|c|c|c|c|c|}
\hline System lifetime (years) & $\begin{array}{c}\text { Power generation over } \\
\text { lifetime }(\mathrm{kWh})\end{array}$ & $\begin{array}{c}\text { Total GHG emissions } \\
\left(\mathrm{kg} \mathrm{CO}_{2}\right)\end{array}$ & $\begin{array}{l}\text { Emission factor } \\
\left(\mathrm{kg} \mathrm{CO}_{2} / \mathrm{kWh}\right)\end{array}$ & $\Delta$ emission factor ${ }^{\dagger}(\%)$ \\
\hline 25 & 296,694 & 51,729 & 0.178 & 15.77 \\
\hline 26 & 307,513 & 51,926 & 0.171 & 12.12 \\
\hline 27 & 318,255 & 52,124 & 0.166 & 8.75 \\
\hline 28 & 328,922 & 52,321 & 0.160 & 5.62 \\
\hline 29 & 339,515 & 52,519 & 0.155 & 2.92 \\
\hline 30 & 350,033 & 52,716 & 0.151 & - \\
\hline 31 & 360,478 & 52,914 & 0.146 & -2.53 \\
\hline 32 & 370,850 & 53,111 & 0.142 & -4.91 \\
\hline 33 & 381,149 & 53,309 & 0.138 & -7.13 \\
\hline 34 & 391,376 & 53,506 & 0.135 & -9.22 \\
\hline 35 & 401,531 & 53,704 & 0.131 & -11.19 \\
\hline
\end{tabular}

${ }^{\dagger}$ Taking a 30-year system lifetime as a reference.

With reference to the obtained average life cycle greenhouse gas (GHG) emissions for the system $\left(150 \mathrm{~g} \mathrm{CO}_{2} \mathrm{eq} /\right.$ $\mathrm{kWh}$ ), it is almost twice the average value for mono-Si PV technology reported by Nugent and Sovacool [29] in a recent metasurvey: $79.5 \mathrm{~g} \mathrm{CO}_{2} \mathrm{eq} / \mathrm{kWh}$. Nonetheless, the authors clarified that the standard deviation was $70.4 \mathrm{~g} \mathrm{CO}_{2} \mathrm{eq} / \mathrm{kWh}$ and the highest reported value was $217 \mathrm{~g} \mathrm{CO}_{2} \mathrm{eq} / \mathrm{kWh}$, significantly higher than the one reported herein. Further, in the studies screened in the metasurvey, only the PV panels were considered, whereas in this study, all the other elements (e.g., wiring and steel support structures) of the system were included in the calculations (i.e., the carbon footprint of the PV panels would be lower).

Apropos of the LCE analysis conducted with PVsyst, it yielded a value of emission savings of 3.54 tons $\mathrm{CO}_{2}$ /year, which implies that it only considered the mix LCE (ca. $0.27 \mathrm{~kg} \mathrm{CO} / \mathrm{kWh}$ ) and neglected the carbon footprint associated with all the PV system life cycle phases except for the use phase.

3.4. Sensitivity Analysis. In estimating potential environmental impacts, LCA, by its very nature, associates with uncertainties [30]. Although an in-depth quantitative sensitivity or uncertainty analysis is beyond the scope of this work, it is worth discussing the influence of factors like the life span or a possible failure of some modules. For instance, in terms of emission savings, a reduction of the lifetime of the system to 25 years, with an associated decrease in the total power generation (down to $296,694 \mathrm{kWh}$ ), would lead to GHG emissions of $0.178 \mathrm{~kg} \mathrm{CO}_{2} / \mathrm{kWh}$, $15.8 \%$ higher than in the 30-year scenario (see Table 4). On the other hand, a 35-year lifetime would lead to an emission factor of $0.131 \mathrm{~kg} \mathrm{CO}_{2} / \mathrm{kWh}(11.2 \%$ lower than for the 30-year life span). 
TABle 5: Impact of the module degradation rate on the emission factor, for a 30 -year system lifetime.

\begin{tabular}{lccc}
\hline $\begin{array}{l}\text { Reduction } \\
\text { in module } \\
\text { efficiency } \\
\text { per year }(\%)\end{array}$ & $\begin{array}{c}\text { Power generation } \\
\text { over lifetime } \\
(\mathrm{kWh})\end{array}$ & $\begin{array}{c}\text { Emission factor } \\
\left(\mathrm{kg} \mathrm{CO}_{2} / \mathrm{kWh}\right)\end{array}$ & $\begin{array}{c}\Delta \text { emission } \\
\text { factor }^{\dagger}(\%)\end{array}$ \\
\hline 0.3 & 370,484 & 0.142 & 5.52 \\
0.4 & 365,228 & 0.144 & 4.16 \\
0.5 & 360,069 & 0.146 & 2.79 \\
0.6 & 355,005 & 0.148 & 1.40 \\
0.7 & 350,033 & 0.151 & - \\
0.8 & 345,152 & 0.153 & -1.41 \\
0.9 & 340,361 & 0.155 & -2.84 \\
1 & 335,656 & 0.157 & -4.28 \\
1.1 & 331,038 & 0.159 & -5.74 \\
\hline
\end{tabular}

${ }^{\dagger}$ Taking a $0.7 \%$ reduction in module efficiency per year as a reference.

Lamnatou et al. [31] reported that the adoption of 30 years (instead of 20 years) led to $31.4 \%$ increase of the avoided impact (i.e., $3.14 \%$ increase per year on average, almost identical to the value found in this study for the 25 to 30 -year range, namely, 3.16\%). Perez et al. [32] also noted that the lifetime assumption greatly affected the environmental performance of PV systems from a life cycle perspective: assuming a functional lifetime of 40 years (instead of 30 years) lowered the GHG emissions by nearly $23 \%$ (i.e., $2.3 \%$ per year on average, in very good agreement with the $2.24 \%$ per year value found in this study for the 30 to 35 -year life span). Barring an unforeseen extreme event, the only elements likely needing replacement before the laminates are the electrical "balance of system" (BoS) components (inverter, fuses, and cabling), if the functional lifetime is to be extended.

The degradation rate can also lead to uncertainty in the LCA. Table 5 summarizes its nonnegligible impact on the emission factor, taking the $0.7 \%$ reduction in the module efficiency as reference (in agreement with IEA recommendations [19]).

In the matter of the failure rate of modules, a default $8 \%$ was chosen for the initial analysis. As shown in Table 6, increasing it by $5 \%$ would lead to an increase in the emission factor of $3.8 \%$ and to an increase in the environmental impact (according to EI-99 methodology) of 2.1\%, associated to the manufacturing, installation, EoL, and so forth of the new panels. Conversely, decreasing the failure rate by the same percentage would reduce the emission factor and the environmental impact by $3.37 \%$ and $2.32 \%$, respectively.

The influence of spectrum and latitude on the annual optical performance would also have an impact on the overall performance of the system and is another source of uncertainty. It should be stressed that the scarcity of case studies on LCA of BI solar thermal, BIPV, BIPVT, and BICPV systems-showcased by Lamnatou et al. [33] in a recent review article about LCA of solar technologies-and the differences between the present study and other studies (in terms of the chosen indicators, the assumptions, the boundaries, the secondary data, data quality, etc.) make it impossible to make direct comparisons (as noted by Gerbinet et al., the achieved improvements of PV technology make it difficult to compare with older LCA publications; BoS components-i.e., all the components of a PV system other than the panel itselfare integrated only in the most recent studies, and the "end of life" (EoL) of the PVs is generally not included either due to the lack of data in this field, in spite of having nonnegligible influence on the results [34]). However, calculating the EPBT (using Cumulative Energy Demand V1.09 method) and greenhouse gas payback time (GPBT) one-dimensional indicators [35] may allow some degree of comparison: for the present case of study, the EPBT was 4.7 years (above the 4.1 harmonized mean value reported in the systematic review and meta-analysis by Bhandari et al. [36], but within the standard deviation) and the GPBT was 3.8 years.

The environmental impact of conventional residential photovoltaic systems in regions with low solar irradiation (900-1000 $\mathrm{kWh} / \mathrm{m}^{2} /$ year, a typical value for Northern Europe and Canada) was investigated by Laleman et al. [37] using EI-99 and other one-dimensional indicators. They reported that the EPBT of residential PV systems (no BoS) was less than 5 years in regions with low solar irradiation, such as Belgium and the UK, and about 2-3 years in regions with high irradiation (such as the south of Europe and central/south U.S.).

Amongst the studies on LCA of mono-Si BIPV systems in different climatic conditions, we may refer, for example, to those by Seng et al. [38], Lu and Yang [39], or Hammond et al. [40]. The former performed a study on the environmental benefits and technical impacts of installing roof-mounted BIPV systems at various locations in Malaysia and estimated that the EPBT values were 3.2-4.4 years for a $1 \mathrm{kWp}$ system. In subtropical Hong Kong, the EPBT of a $22 \mathrm{kWp}$ roofmounted system was 7.1 years and the GPBT was 5.2 years, with respect to fuel mix of local power stations [39]. In the UK, Hammond et al. [40] studied a $2.1 \mathrm{kWp}$ roof-mounted system, including all BoS components required for an electrical grid connection but neglecting the EoL disposal of the system. The EPBT was estimated to be 4.5 years, and the "carbon payback period" was 4 years. In the US, Perez et al. [32] studied a $11.3 \mathrm{kWp}$ system installed in New York and, in the 30-year scenario in which the wafers were not coming from waste stream, the system's EPBT was 3.81 years and the GWP calculated by the IPCC GWP 100 methodology was $60.5 \mathrm{~g} \mathrm{CO}_{2} / \mathrm{kWh}$ (although EoL was neglected).

Concerning more recent studies on BICPV systems (which show about $13 \%$ lower impact per $\mathrm{kWp}$ than the BIPV systems without concentration due to the fact that there is less PV cell material [13]), Baig et al. [41] found that the average difference in the annual performance of a BICPV system when evaluated for six different geographic locations with latitudes in the $40.4^{\circ}$ to $64.73^{\circ}$ range was only $1.25 \%$. This almost constant performance in the annual energy output was ascribed to the fact that, although the total annual irradiation on the plane of the panel clearly decreases with the latitude, the optical efficiency increases with the latitude (due to the progressive red shift of the incident spectra). However, Lamnatou et al. have brought to attention in several of their works that certain results/conclusions of the 
TABLE 6: Impact of the module failure rate on the emission factor and on EI-99 impact estimation.

\begin{tabular}{lccccc}
\hline Failure rate (\%) & $\begin{array}{c}\text { Total GHG emissions } \\
\left(\mathrm{kg} \mathrm{CO}_{2}\right)\end{array}$ & $\begin{array}{c}\text { Emission factor } \\
\left(\mathrm{kg} \mathrm{CO}_{2} / \mathrm{kWh}\right)\end{array}$ & $\Delta$ emission factor $^{\dagger}(\%)$ & $\begin{array}{c}\text { EI-99 impact for } \\
\text { entire system (kPt) }\end{array}$ & $\Delta$ EI-99 impact ${ }^{\dagger}(\%)$ \\
\hline 13 & 54,722 & 0.156 & 3.81 & 9.781 & 2.09 \\
12 & 54,278 & 0.155 & 2.96 & 9.811 & 1.79 \\
11 & 53,643 & 0.153 & 1.76 & 9.862 & 1.28 \\
10 & 53,195 & 0.152 & 0.91 & 9.909 & 0.81 \\
9 & 53,164 & 0.152 & 0.85 & 9.920 & 0.70 \\
8 & 52,716 & 0.151 & - & 9.990 & - \\
7 & 52,084 & 0.149 & -1.20 & 10.041 & -0.51 \\
6 & 52,053 & 0.149 & -1.26 & 10.052 & -0.62 \\
5 & 51,605 & 0.147 & -2.11 & 10.103 & -1.13 \\
4 & 51,158 & 0.146 & -2.96 & 10.169 & -1.79 \\
3 & 50,942 & 0.146 & -3.37 & 10.221 & -2.32 \\
\hline
\end{tabular}

${ }^{\dagger}$ Taking an $8 \%$ failure rate as a reference.

LCA (depending on the impact category/environmental indicator) are strongly influenced by the adopted electricity mixes. In a study of a BICPV system for different cities (Barcelona, Exeter, and Dublin) [31], they found that the EI-99-based PBT values ranged from 5.1 (Barcelona) to 7.8 years (Exeter). In another study on a BICPV system for Exeter, Barcelona, Madrid, Dublin, and Paris [42], they found that Paris, Exeter, and Dublin showed EPBT values around $45 \%$ higher than Barcelona and Madrid. When they investigated the environmental profile of a dielectric-based 3D BICPV device for different cities (Barcelona, Seville, Paris, Marseille, London, and Aberdeen) [28], they found that Barcelona had the lowest GHG PBTs, ranging from 3.23 to 3.83 years (without material replacement), in line with the 3.8 value obtained for this case of study, while for the studied French cities these values ranged from 17.91 to 37.48 years (such high GHG PBTs for Paris and Marseille are associated with the low $\mathrm{CO}_{2}$ emissions of France's electricity, due to its particular characteristics, with a high penetration of nuclear energy). Marseille was the city with the lowest EPBT, almost half of Aberdeen's (4.1 years), due the high CPV output in combination with the fact that France's electricity had higher CED/kWh in comparison with Spain and UK.

Finally, another important aspect in terms of the uncertainty of the LCA would be related to the shading effect of the BIPV system. Given that the façade of the lecture hall is oriented to the south, there were significant heat and glare problems in the classrooms that led to the lowering of blinds and the use of artificial light during the day. The installation of the BIPV shading panels above the windows, projecting out for a meter from the façade, has allowed full visibility from the inside while blocking off direct sunlight, significantly reducing aforementioned unwanted heat and excessive glare in the classrooms. Since the use of artificial light will thus be reduced, the electricity consumption of the building from now onwards should actually be lower than the values indicated in Section 2.1, and the real environmental savings would, in turn, be higher. Consequently, the results obtained from the LCA should be regarded as a lower estimate [43].

\section{Conclusions}

As part of a framework strategy for a resilient energy union with a forward-looking climate change policy, the EU has placed emphasis both on the construction of new NZEB buildings and on the transformation of existing buildings into NZEBs. The design of a PV system integrated into one of these later buildings (a lecture hall of the University of Valladolid, Spain), validated with PVsyst tool, is presented. The LCA of the BIPV system over a 30-year span was conducted using two damage-oriented LCIA methodologies (EPS2000 and EI-99), which agreed in the significant impact associated with the wiring system, close to that of the PV manufacturing. The assessment of the BIPV system environmental impact as a replacement of the energy resources used in the Spanish power grid mix indicated that a significant impact reduction (53\%) would be achieved through the installation of the BIPV system. The results from the IPCC 2013 methodology further supported this claim, since the PV system led to a $67 \%$ lower carbon footprint.

\section{Conflicts of Interest}

The authors declare that there is no conflict of interest regarding the publication of this article.

\section{Acknowledgments}

The authors would like to gratefully acknowledge the financial support by Consejería de Educación de la Junta de Castilla y León through Project no. VA029U16.

\section{References}

[1] E. Annunziata, M. Frey, and F. Rizzi, "Towards nearly zeroenergy buildings: the state-of-art of national regulations in Europe," Energy, vol. 57, pp. 125-133, 2013. 
[2] H. Erhorn and H. Erhorn-Kluttig, "Towards 2020 - nearly zero-energy buildings, overview and outcomes," in Implementing the Energy Performance of Buildings Directive (EPBD)-Featuring Country Reports 2012, E. Maldonado, Ed., pp. 57-74, Portuguese Energy Agency (ADENE), Lisbon, Portugal, 2015.

[3] J.-H. Kim, H.-R. Kim, and J.-T. Kim, "Analysis of photovoltaic applications in zero energy building cases of IEA SHC/EBC task 40/Annex 52," Sustainability, vol. 7, no. 7, pp. 87828800, 2015.

[4] C. Cornaro, G. Basciano, V. Puggioni, and M. Pierro, "Energy saving assessment of semi-transparent photovoltaic modules integrated into NZEB," Buildings, vol. 7, no. 1, p. 9, 2017.

[5] A. Mohamed, A. Hasan, and K. Sirén, "Fulfillment of net-zero energy building (NZEB) with four metrics in a single family house with different heating alternatives," Applied Energy, vol. 114, pp. 385-399, 2014.

[6] E. Pikas, J. Kurnitski, M. Thalfeldt, and L. Koskela, "Costbenefit analysis of nZEB energy efficiency strategies with on-site photovoltaic generation," Energy, vol. 128, pp. 291301, 2017.

[7] T. Niemelä, R. Kosonen, and J. Jokisalo, "Energy performance and environmental impact analysis of cost-optimal renovation solutions of large panel apartment buildings in Finland," Sustainable Cities and Society, vol. 32, pp. 9-30, 2017.

[8] M. Cellura, F. Guarino, S. Longo, and M. Mistretta, "Energy life-cycle approach in net zero energy buildings balance: operation and embodied energy of an Italian case study," Energy and Buildings, vol. 72, pp. 371-381, 2014.

[9] F. Ascione, N. Bianco, R. F. De Masi, G. M. Mauro, and G. P. Vanoli, "Energy retrofit of educational buildings: transient energy simulations, model calibration and multi-objective optimization towards nearly zero-energy performance," Energy and Buildings, vol. 144, pp. 303-319, 2017.

[10] T. Niemelä, R. Kosonen, and J. Jokisalo, "Cost-optimal energy performance renovation measures of educational buildings in cold climate," Applied Energy, vol. 183, pp. 1005-1020, 2016.

[11] O. Irulegi, A. Ruiz-Pardo, A. Serra, J. M. Salmerón, and R. Vega, "Retrofit strategies towards net zero energy educational buildings: a case study at the University of the Basque Country," Energy and Buildings, vol. 144, pp. 387-400, 2017.

[12] I. Baran, L. Dumitrescu, and R. A. Pescaru, "Thermal rehabilitation technology and the nearly zero-energy buildings. Romanian representative education buildings-case study," Procedia Technology, vol. 22, pp. 358-364, 2016.

[13] K. Menoufi, D. Chemisana, and J. I. Rosell, "Life cycle assessment of a building integrated concentrated photovoltaic scheme," Applied Energy, vol. 111, pp. 505-514, 2013.

[14] J. M. Sancho Ávila, J. Riesco Martín, C. Jiménez Alonso, M. C. Sánchez de Cos Escuin, J. Montero Cadalso, and M. López Bartolomé, Atlas de Radiación Solar en España utilizando datos del SAF de Clima de EUMETSAT, MAPAMA, Madrid, Spain, 2012.

[15] C. Zomer and R. Rüther, "Simplified method for shading-loss analysis in BIPV systems - part 1: theoretical study," Energy and Buildings, vol. 141, pp. 69-82, 2017.

[16] D. Hasapis, N. Savvakis, T. Tsoutsos, K. Kalaitzakis, S. Psychis, and N. P. Nikolaidis, "Design of large scale prosuming in universities: the solar energy vision of the TUC campus," Energy and Buildings, vol. 141, pp. 39-55, 2017.

[17] A. Ghazali, E. I. Salleh, L. C. Haw, S. Mat, and K. Sopian, "Performance and financial evaluation of various photovoltaic vertical facades on high-rise building in Malaysia," Energy and Buildings, vol. 134, pp. 306-318, 2017.

[18] A. Skoczek, T. Sample, and E. D. Dunlop, "The results of performance measurements of field-aged crystalline silicon photovoltaic modules," Progress in Photovoltaics: Research and Applications, vol. 17, no. 4, pp. 227-240, 2009.

[19] R. Frischknecht, G. Heath, M. Raugei, P. Sinha, and M. de Wild-Scholten, Methodology Guidelines on Life Cycle Assessment of Photovoltaic Electricity (Report IEA-PVPS T12-06:2016), International Energy Agency (IEA) PVPS Task 12, Paris, France, 3rd edition, 2016.

[20] M. Weißenberger, W. Jensch, and W. Lang, "The convergence of life cycle assessment and nearly zero-energy buildings: the case of Germany," Energy and Buildings, vol. 76, pp. 551557, 2014.

[21] L. F. Cabeza, L. Rincón, V. Vilariño, G. Pérez, and A. Castell, "Life cycle assessment (LCA) and life cycle energy analysis (LCEA) of buildings and the building sector: a review," Renewable and Sustainable Energy Reviews, vol. 29, pp. 394-416, 2014.

[22] A. Sharma, A. Saxena, M. Sethi, V. Shree, and Varun, "Life cycle assessment of buildings: a review," Renewable and Sustainable Energy Reviews, vol. 15, no. 1, pp. 871-875, 2011.

[23] S. Deng, R. Z. Wang, and Y. J. Dai, "How to evaluate performance of net zero energy building - a literature research," Energy, vol. 71, pp. 1-16, 2014.

[24] A. Vilches, A. Garcia-Martinez, and B. Sanchez-Montañes, "Life cycle assessment (LCA) of building refurbishment: a literature review," Energy and Buildings, vol. 135, pp. 286301, 2017.

[25] R. Frischknecht, R. Itten, P. Sinha et al., Life Cycle Inventories and Life Cycle Assessment of Photovoltaic Systems (Report T12-04:2015), International Energy Agency (IEA) PVPS Task 12, Paris, France, 2015.

[26] C. E. L. Latunussa, F. Ardente, G. A. Blengini, and L. Mancini, "Life cycle assessment of an innovative recycling process for crystalline silicon photovoltaic panels," Solar Energy Materials and Solar Cells, vol. 156, pp. 101-111, 2016.

[27] IPCC, Climate Change 2013: The Physical Science Basis. Contribution of Working Group I to the Fifth Assessment Report of the Intergovernmental Panel on Climate Change, Cambridge University Press, Cambridge, United Kingdom and New York, NY, USA, 2014.

[28] C. Lamnatou, H. Baig, D. Chemisana, and T. K. Mallick, "Dielectric-based 3D building-integrated concentrating photovoltaic modules: an environmental life-cycle assessment," Energy and Buildings, vol. 138, pp. 514-525, 2017.

[29] D. Nugent and B. K. Sovacool, “Assessing the lifecycle greenhouse gas emissions from solar PV and wind energy: a critical meta-survey," Energy Policy, vol. 65, pp. 229-244, 2014.

[30] J. Ling-Chin, O. Heidrich, and A. P. Roskilly, "Life cycle assessment (LCA) - from analysing methodology development to introducing an LCA framework for marine photovoltaic (PV) systems," Renewable and Sustainable Energy Reviews, vol. 59, pp. 352-378, 2016.

[31] C. Lamnatou, H. Baig, D. Chemisana, and T. K. Mallick, "Environmental assessment of a building-integrated linear dielectric-based concentrating photovoltaic according to multiple life-cycle indicators," Journal of Cleaner Production, vol. 131, pp. 773-784, 2016. 
[32] M. J. R. Perez, V. Fthenakis, H.-C. Kim, and A. O. Pereira, "Façade-Integrated photovoltaics: a life cycle and performance assessment case study," Progress in Photovoltaics: Research and Applications, vol. 20, no. 8, pp. 975-990, 2012.

[33] C. Lamnatou, D. Chemisana, R. Mateus, M. G. Almeida, and S. M. Silva, "Review and perspectives on life cycle analysis of solar technologies with emphasis on building-integrated solar thermal systems," Renewable Energy, vol. 75, pp. 833846, 2015.

[34] S. Gerbinet, S. Belboom, and A. Léonard, "Life cycle analysis (LCA) of photovoltaic panels: a review," Renewable and Sustainable Energy Reviews, vol. 38, pp. 747-753, 2014.

[35] F. Cucchiella and I. D'Adamo, "Estimation of the energetic and environmental impacts of a roof-mounted building-integrated photovoltaic systems," Renewable and Sustainable Energy Reviews, vol. 16, no. 7, pp. 5245-5259, 2012.

[36] K. P. Bhandari, J. M. Collier, R. J. Ellingson, and D. S. Apul, "Energy payback time (EPBT) and energy return on energy invested (EROI) of solar photovoltaic systems: a systematic review and meta-analysis," Renewable and Sustainable Energy Reviews, vol. 47, pp. 133-141, 2015.

[37] R. Laleman, J. Albrecht, and J. Dewulf, "Life cycle analysis to estimate the environmental impact of residential photovoltaic systems in regions with a low solar irradiation," Renewable and Sustainable Energy Reviews, vol. 15, no. 1, pp. 267-281, 2011.

[38] L. Y. Seng, G. Lalchand, and G. M. Sow Lin, "Economical, environmental and technical analysis of building integrated photovoltaic systems in Malaysia," Energy Policy, vol. 36, no. 6 , pp. 2130-2142, 2008.

[39] L. Lu and H. X. Yang, "Environmental payback time analysis of a roof-mounted building-integrated photovoltaic (BIPV) system in Hong Kong," Applied Energy, vol. 87, no. 12, pp. 3625-3631, 2010.

[40] G. P. Hammond, H. A. Harajli, C. I. Jones, and A. B. Winnett, "Whole systems appraisal of a UK building integrated photovoltaic (BIPV) system: energy, environmental, and economic evaluations," Energy Policy, vol. 40, pp. 219-230, 2012.

[41] H. Baig, E. F. Fernández, and T. K. Mallick, "Influence of spectrum and latitude on the annual optical performance of a dielectric based BICPV system," Solar Energy, vol. 124, pp. 268-277, 2016.

[42] C. Lamnatou, H. Baig, D. Chemisana, and T. K. Mallick, "Life cycle energy analysis and embodied carbon of a linear dielectric-based concentrating photovoltaic appropriate for building-integrated applications," Energy and Buildings, vol. 107, pp. 366-375, 2015.

[43] P. Jayathissa, M. Jansen, N. Heeren, Z. Nagy, and A. Schlueter, "Life cycle assessment of dynamic building integrated photovoltaics," Solar Energy Materials and Solar Cells, vol. 156, pp. 75-82, 2016. 

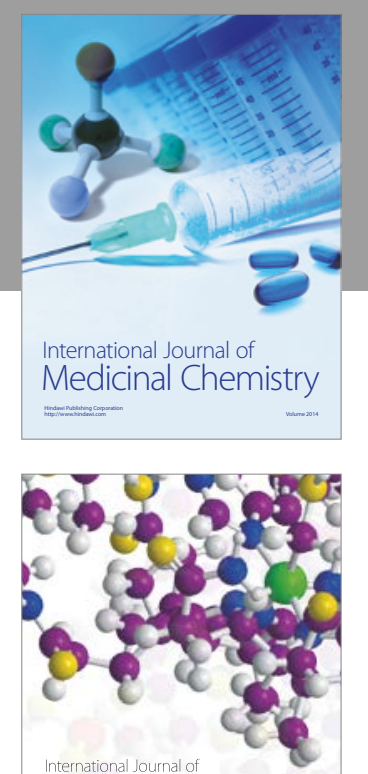

Carbohydrate Chemistry

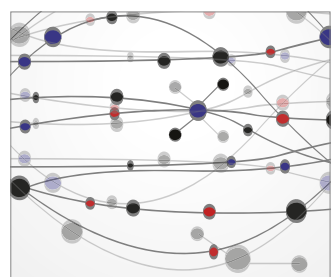

The Scientific World Journal
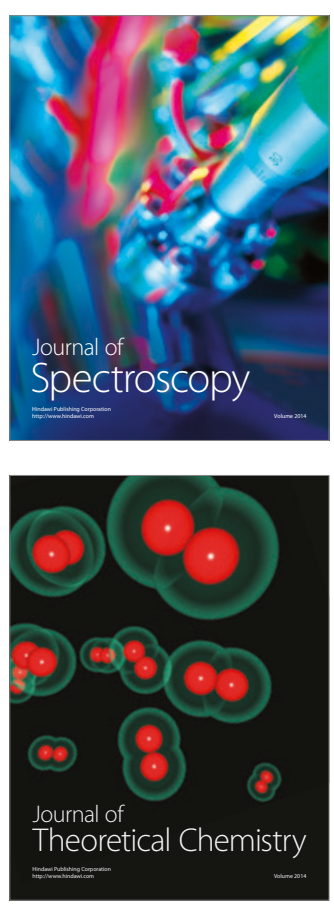
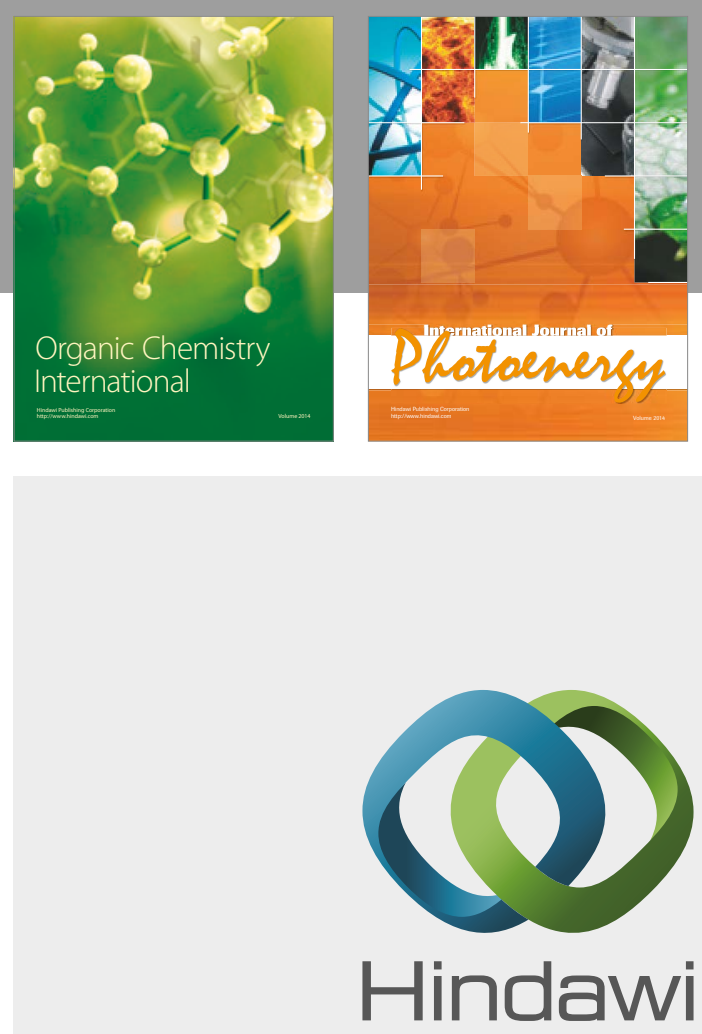

Submit your manuscripts at

https://www.hindawi.com

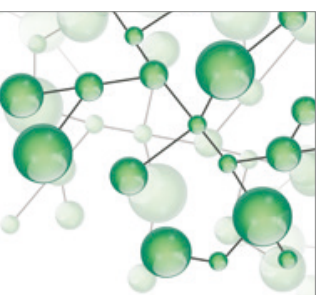

International Journal of

Inorganic Chemistry

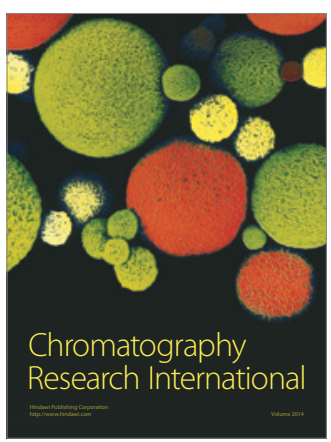

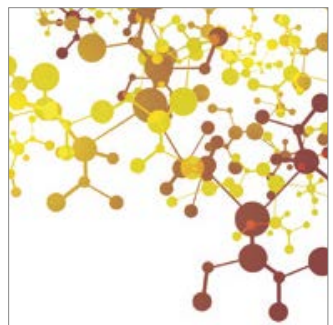

Applied Chemistry
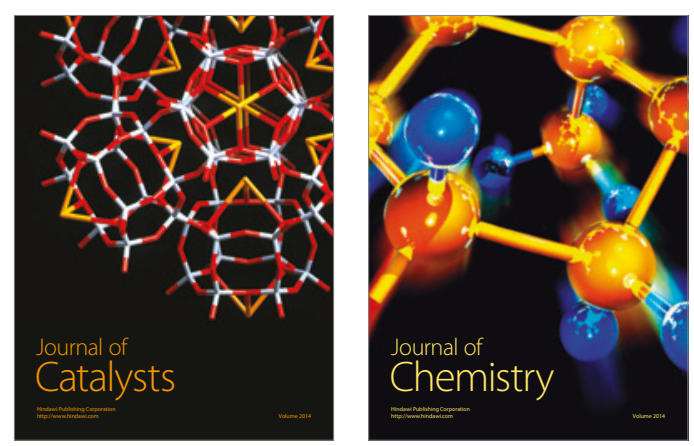
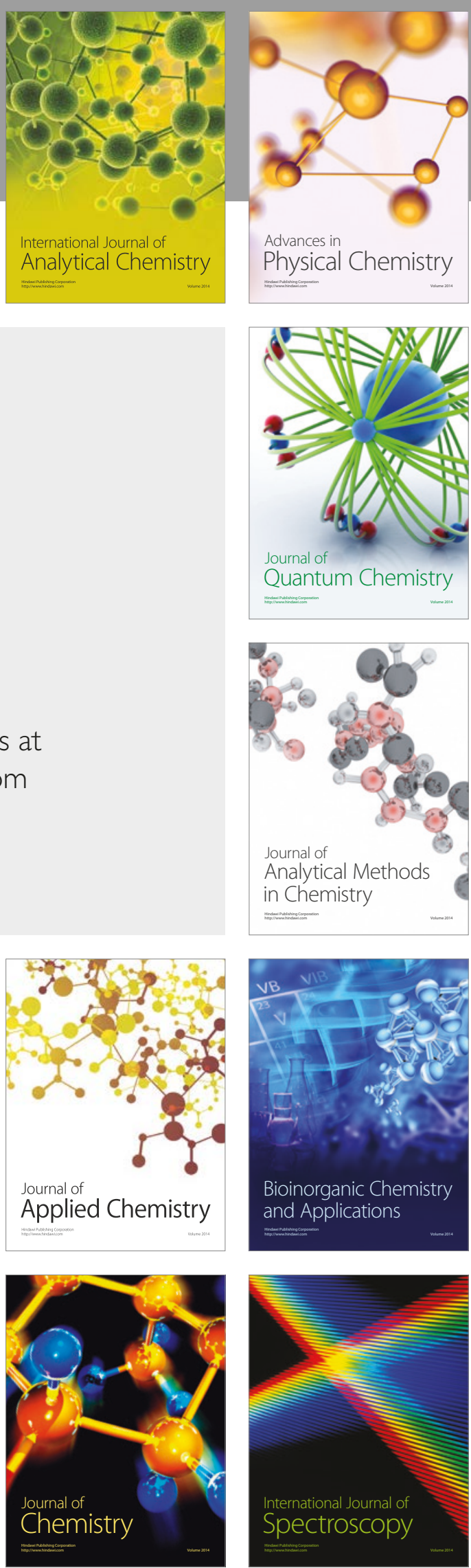